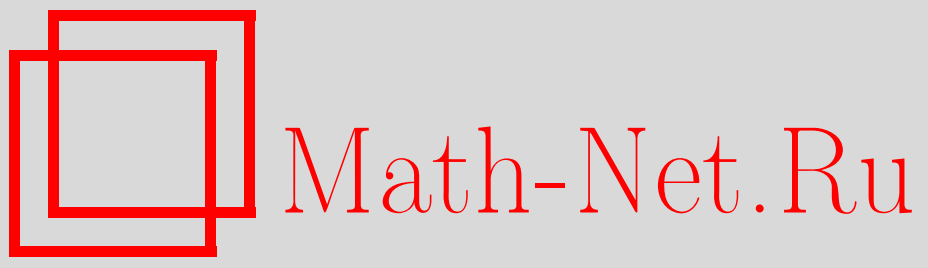

Информация о двенадцатой Колмогоровской студенческой олимпиаде по теории вероятностей, Теория вероятн. и ее примен., 2014, том 59, выпуск 1, 202-204

DOI: https://doi.org/10.4213/tvp4560

Использование Общероссийского математического портала Math-Net.Ru подразумевает, что вы прочитали и согласны с пользовательским соглашением http://www.mathnet.ru/rus/agreement

Параметры загрузки:

IP : 34.229 .45 .116

26 апреля 2023 г., 16:18:03

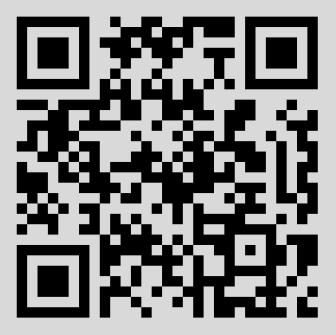




\section{ИНФОРМАЦИЯ О ДВЕНАДЦАТОЙ КОЛМОГОРОВСКОЙ СТУДЕНЧЕСКОЙ ОЛИМПИАДЕ ПО ТЕОРИИ ВЕРОЯТНОСТЕЙ}

В ознаменование дня рождения А. Н. Колмогорова кафедра теории вероятностей механико-математического факультета Московского государственного университета им. М. В. Ломоносова провела двенадцатую Колмогоровскую студенческую олимпиаду по теории вероятностей. Информация о предыдущих Колмогоровских олимпиадах содержится на сайте кафедры теории вероятностей (http://mech.math.msu.su/probab).

Олимпиада была проведена 20 апреля 2013 года раздельно для I-II и III-V курсов (продолжительность - 5 часов). В олимпиаде приняли участие и сдали работы 34 студента I-II курсов и 9 студентов III-V курсов механико-математического факультета Московского государственного университета, а также факультета вычислительной математики и кибернетики и физического факультета Московского государственного университета.

\section{Задачи олимпиады}

В скобках после номера задачи (или пункта задачи) указываются курсы, на которых предлагалась данная задача, затем число решивших ее студентов I-II курсов, и, наконец, число решивших ее студентов III-V курсов (для задач, которые предлагались только в одной возрастной категории, приведено только число решивших).

Задача 1. (I-V; 4, 7) Пусть $X$ и $Y$ - независимые одинаково распределенные неотрицательные случайные величины с конечной дисперсией. Верно ли, что $\mathbf{D} \min \{X, Y\} \leqslant \mathbf{D} X ?$

Задача 2. (I-V; 4, 3) Пусть $X$ и $Y$ - дискретные случайные величины на общем вероятностном пространстве, причем известны все условные вероятности $\mathbf{P}(X=x \mid Y=y)$ и $\mathbf{P}(Y=y \mid X=x)$ (при всех $x, y \in \mathbf{R}$, для которых они определены). Верно ли, что можно однозначно определить совместное распределение $X$ и $Y$ ?

Задача 3. (I-V; 4, 6) На отрезок $[0,1]$ случайным образом бросают $n$ точек. Для каждой из точек равновероятно и независимо от ее положения и от других точек выбирается направление движения (вправо или влево). Затем точки одновременно начинают движение со скоростью 1. Все столкновения точек абсолютно упругие (т.е. после столкновения каждая из двух точек начинает движение в противоположном направлении с той же скоростью), а при достижении границы отрезка точка к ней прилипает. Найти математическое ожидание момента, когда прилипнет последняя точка.

Задача 4. (I-V; 1, 4) Найти $\lim _{n \rightarrow \infty} \int_{[0,1]^{n}}\left(x_{1}^{5}+\cdots+x_{n}^{5}\right) /\left(x_{1}^{4}+\cdots+x_{n}^{4}\right) d x$.

Задача 5. (I-V; 1,5$)$ Вероятностная мера $\mu$ на числовой прямой задается следующим образом: $\mu([0,1])=1, \mu([0,1 / 3])=\mu([2 / 3,1])=1 / 2, \mu([0,1 / 9])=\mu([2 / 9,1 / 3])=$ $\mu([2 / 3,7 / 9])=\mu([8 / 9,1])=1 / 4$ и т.д. Пусть случайная величина $X$ имеет распределение $\mu$. Найти дисперсию $X$.

Задача 6. (I-V; 0,1$)$ Пусть $S_{0}=0$ и $S_{n}=\sum_{i=1}^{n} X_{i}, n \in \mathbf{N}$, где независимые одинаково распределенные случайные величины $\left\{X_{i}, i \in \mathbf{N}\right\}$ принимают значения 1 и -1 с вероятностями $1 / 2$. Найти математическое ожидание момента $\tau=\inf \{k>0$ : $\left.\max _{i \leqslant k} S_{i}-\min _{i \leqslant k} S_{i}=m\right\}$ (при $m \in \mathbf{N}$ ). 
Задача 7. Пусть $X$ и $Y$ - независимые одинаково распределенные случайные величины с конечным математическим ожиданием. Доказать, что $\mathbf{E}|X-Y| \leqslant \mathbf{E} \mid X+$ $Y \mid$, если

(a) (I-II; 0) у этих случайных величин есть плотность;

(b) (III-V; 0) у этих случайных величин, возможно, нет плотности.

Задача 8. (I-V; 0,1$)$ Пусть $f(t)$ есть четная $2 \pi$-периодическая функция, обладающая следующими свойствами: на отрезке $[0,2 \pi]$ ее график совпадает с графиком квадратного трехчлена, причем $f(0)=1$. Определить, при каких $f(\pi)$ функция $f$ является характеристической функцией некоторого распределения, и найти это распределение.

Задача 9. (III-V; 1) Пусть $W=\{W(t), t \geqslant 0\}-$ винеровский процесс. Доказать, что его максимум на отрезке $[0,1]$ с вероятностью единица достигается в единственной точке.

\section{Победители олимпиады}

Разбор задач и награждение победителей проводились на Большом семинаре кафедры теории вероятностей 8 мая 2013 года.

\section{Победители среди студентов I-II курсов Первая премия}

Почеревин Роман Александрович - студент II курса механико-математического факультета Московского государственного университета (2,5 решенных задач).

\section{Вторая премия}

Калашников Иван Александрович - студент II курса механико-математического факультета Московского государственного университета (2 решенные задачи).

Заночкин Андрей Юрьевич - студент II курса факультета вычислительной математики и кибернетики Московского государственного университета (2 решенные задачи).

\section{Третья премия}

Стасюк Тарас Андреевич - студент II курса механико-математического факультета Московского государственного университета (1,5 решенных задач).

\section{Победители среди студентов III-V курсов}

\section{Первая премия}

Шульчевский Дмитрий Игоревич - студент V курса механико-математического факультета Московского государственного университета (7 решенных задач), научный руководитель - А. П. Шашкин.

\section{Третья премия}

Ивлев Федор Алексеевич - студент III курса механико-математического факультета Московского государственного университета (3 решенные задачи), научный руководитель - А. В. Михалев.

Лавров Петр Аркадьевич - студент III курса механико-математического факультета Московского государственного университета (3 решенные задачи), научный руководитель - А. В. Михалев.

Машников Олег Васильевич - студент III курса механико-математического факультета Московского государственного университета (3 решенные задачи), научный руководитель - А. А. Замятин.

Парамонов Кирил Борисович - студент V курса механико-математического факультета Московского государственного университета (3 решенные задачи), научный руководитель - А. П. Шашкин. 
Токарев Игорь Вячеславович - студент I курса магистратуры механикоматематического факультета Московского государственного университета (3 решенные задачи), научный руководитель - А. Н. Ширяев.

10 мая 2013 г.

Оргкомитет двенадчатой Колмогоровской студенческой олимпиады по теории вероятностей:

академик РАН, профессор А.Н. Ширяев,

к.ф.-м.н., дочент А.П. Шашкин,

к.ф.-м.н., дочент М. М. Мусин,

к. ..-м.н., ассистенты Е. Е. Баштова, П. А. Яськов,

аспирантьи, О. А. Бутковский, Я. А. Люлько,

Ю. А. Мальикин, А. Ю. Хапланов 